\title{
Analysis of geomagnetic secular variation for the last 1.5 Ma recorded by volcanic rocks of the Trans Mexican Volcanic Belt: New data from Sierra de Chichinautzin, Mexico.
}

Rodríguez-Trejo, A..,*, Alva-Valdivia, L. M. ${ }^{2}$, Perrin, M. ${ }^{3}$, Hervé, G. ${ }^{3}$, López-Valdés, N. ${ }^{1}$

${ }^{1}$ Posgrado en Ciencias de la Tierra, Instituto de Geofísica, Universidad Nacional Autónoma de México, Circuito de la Investigación Científica, C.P. 04510 México D. F., México ${ }^{2}$ Laboratorio de Paleomagnetismo, Instituto de Geofísica, Universidad Nacional Autónoma de México, Circuito de la Investigación Científica, C.P. 04510 México D. F., México

${ }^{3}$ Aix Marseille Univ, CNRS, IRD, INRA, Coll France, CEREGE, Aix-en-Provence, France

Corresponding author: alekz_igf@hotmail.com

Keywords: paleomagnetic secular variation, rock and mineral magnetism, Sierra de Chichinautzin volcanic field, regional analysis, Trans Mexican Volcanic Belt, Mexico 


\begin{abstract}
The great wealth of volcanism along the Trans Mexican Volcanic Belt (TMVB) and the need to improve the secular variation curve of the Earth magnetic field of the region is the aim of this research. 300 oriented cores from 33 sites and 21 individual cooling units were acquired from Sierra de Chichinautzin volcanic field (ChVF) and Sierra de Santa Catarina (SSC). Directional analysis and rock magnetic experiments were performed (e.g. thermal demagnetization, hysteresis loop, susceptibility $v s$. temperature), achieving 21 new averaged paleomagnetic directions. New results are consistent with the previous studies on the same cooling unit. We compiled all the paleomagnetic studies performed on the ChVF, updating age and calculating an average direction per cooling unit and estimating an overall mean direction for the $\mathrm{ChVF}\left(\mathrm{Dec}=359.1^{\circ}, \mathrm{Inc}=35.3^{\circ}, \mathrm{N}=33, \mathrm{k}=21.6, \alpha 95=5.5^{\circ}, \mathrm{Plat}=87.7^{\circ} \mathrm{N}\right.$, Plong $=227.4^{\circ} \mathrm{E}, \mathrm{K}=31.8$, A95 $=4.5^{\circ}$ ).

Afterwards, we compiled all the previous paleomagnetic studies along the whole TMVB with age ranging from 0 to $1.5 \mathrm{Ma}$, and constrained the directional analyses by specific quality criteria such as well-defined age, number of samples and quality of kappa) on the cooling unit consistency.

The mean direction and virtual geomagnetic pole (VGP) estimated for the TMVB, during the periods 0-40 ka and 0-1.5 Ma, are close to the geographic pole, supporting the validity of the geocentric axial dipole hypothesis. The directional results of this study also fit well with the predictions at Mexico City of the models SHA.DIF.14k and CALS10k2 calculated for the last $14 \mathrm{ka}$. The dispersion of the VGP's on the TMVB are also consistent with the expected values proposed by different models of paleosecular variation (e.g. Opdyke et al., 2015; Cromwell et al., 2018). However, large gaps in the temporal record remain that should be filled by further paleomagnetic studies.
\end{abstract}

\title{
1. Introduction
}

The Earth's magnetic field, mainly generated in the core of the Earth, has temporal and spatial variations in direction and intensity recorded by diverse geologic materials, as volcanic rocks, archaeological materials or sediments. However, sediments that can give only relative paleointensity estimates will not be considered here. Global models were developed using data repositories, e.g. MagIC (https://www2.earthref.org/MagIC) or GEOMAGIA50.v3 (Brown et al., 2015), to characterize the behaviour and the variation through time of the geodynamo. For the last millennia, models as CALS10k.2 and ARCH10k.1 (Constable et al., 2016), SHA.DIF.14k (Pavón-Carrasco, et al., 2014) were computed by spherical harmonic analysis in space.

An accurate modelling requires a homogeneous spatial distribution of data over the globe. But the present distribution is strongly biased towards mid-latitudes of the northern hemisphere (e.g. Panovska et al., 2018), emphasizing the need of data from low latitudes and the Southern hemisphere. Mexico is a key area through its rich archaeological past and its intense and continuous volcanic activity for millions of years. Of particular interest, the TMVB is an active volcanic arc, characterized by thousands of volcanic structures that cross central Mexico from East to West (Fig. 1a). In the TMVB, two important volcanic fields were emplaced from late Pleistocene to Holocene: the Michoacán-Guanajuato Volcanic Field (MGVF, Figure 1b) in west-central Mexico (e.g. González, et al., 1997; Michalk et al., 2013; Mahgoub et al., 2017, 2019), and the ChVF (Figure 1b) in central Mexico. There were many paleomagnetic studies focusing on field directions and intensities, during the last 30 years (e.g. Herrero-Bervera and Pal, 1977; Urrutia-Fucugauchi and Martin Del Pozzo, 1993; Böhnel et al., 2003; Alva-Valdivia, 2005), but new radiocarbon and argon-argon ages, obtained in the 
past 15 years (e.g. Siebe, et al., 2004b, Guilbaud, et al., 2015, Jaimes-Viera, et al., 2018) open exciting perspectives for secular variation studies.

In this work, we acquired new palaeomagnetic data from Sierra de Chichinautzin Volcanic Field (ChVF) and Sierra de Santa Catarina (SSC), which were analyzed together with previous published data on rocks with well-defined age. Next, a compilation and critical analysis of the available volcanic paleomagnetic data from the TMVB improved the understanding of the variation of the geomagnetic field during the late Pleistocene and Holocene in central Mexico.

\section{Geology, chronology and sampling}

The TMVB is a volcanic arc, 1000-km-long belt extending from the Pacific Ocean to the Gulf of Mexico, formed by subduction along the Acapulco trench, since middle Miocene (ca. 16 Ma) to present day (Ferrari et al., 1994, 1999). The TMVB is roughly a W-E oriented transverse belt, formed by numerous Mexican geological provinces (Ortega-Gutiérrez et al., 1992; Aguirre-Díaz et al., 1998). This geometry exposes a configuration of volcanic vents, which include abundant scoria cones grouped in extensive monogenetic volcanic fields, such as the ChVF (Fig. 1). The variations in the subduction angle of the Cocos plate, chemical assemblages, type of volcanism, change in arc width, and the existence of intraplate subduction-related alkaline volcanism, divide the TMVB into three portions: eastern, central, and western (Ferrari, 2000; Gómez-Tuena et al., 2007). The scoria cones and related volcanic deposits studied here are part of the central TMVB. During the Pleistocene, more than 8,000 volcanic structures, such as stratovolcanoes, scoria and cinder cones, were formed (Demant, 1978; Aguirre-Díaz, et al., 1998).

The ChVF, a still active hazardous volcanic field, consists of more than 220 monogenetic volcanic structures of wide compositional range. The activity started 1.6 Ma ago and the last eruption, the Xitle volcano, was dated at $1.6 \mathrm{ka} \mathrm{BP} \mathrm{(e.g.} \mathrm{Martin} \mathrm{del} \mathrm{Pozzo,} \mathrm{1982;}$ Siebe et al., 2004a; Arce et al., 2013). The eruption rate was estimated around $0.016 \mathrm{~km}^{3} / \mathrm{ka}$ per $100 \mathrm{~km}^{2}$ for the whole volcanic field (Arce et al., 2013) and around $0.6 \mathrm{~km}^{3} / \mathrm{ka}$ during the Holocene (Siebe et al., 2005). Close to the ChVF is located the SSC monogenetic volcanic group (units $4 \& 8$ in Fig. 1b) with seven volcanoes formed by lava flows and pyroclastic deposits, ranging in age from 132 to $2 \mathrm{ka}$ (Jaimes-Viera et al., 2018).

Our paleomagnetic sampling focused on 21 well-dated volcanic cooling units from the ChVF and SSC (Table 1). A cooling unit is defined here as a volcanic event, during which rocks were emplaced and cooled rapidly, recording almost instantaneously the Earth Magnetic Field. One up to six paleomagnetic sites have been sampled in a given cooling unit. Ten cooling units were dated using the radiocarbon technique. The uncalibrated ages given in the original papers were carefully analyzed and updated when possible (Table 1). For example, Gonzalez et al. (1997) reported a ${ }^{14} \mathrm{C}$ age of $4070 \pm 150$ uncalibrated BP (Kirianov et al., 1990) for the El Pelado volcano but we retained only the three ages, 9620 $\pm 160,10270 \pm 190$ and $10900 \pm 280$ uncalibrated BP, from Siebe (2004b). All radiocarbon ages were calibrated using the most recent version of the calibration curve Intcal13 (Reimer et al, 2013). The age of seven others cooling units were defined using recent Argon-Argon dates (Arce et al, 2013; Jaimes Viera et al, 2018). Finally, four cooling units could not be dated more precisely than by their stratigraphic constraints with other cooling units.

The sampling was distributed in three groups: a) the younger group of age ranging from $2 \mathrm{ka}$ to $40 \mathrm{ka}$; b) the older group of age from $40 \mathrm{ka}$ to $1.2 \mathrm{Ma}$, sampling volcanic structures, and c) Sierra de Santa Catarina monogenetic volcanic group. The samples were collected in- 
situ, avoiding fractured and displaced blocks. All samples were drilled directly in the field with a portable gasoline powered drill, and oriented with magnetic and sun compasses. A total of 300 cores, one inch in diameter and 6 to $15 \mathrm{~cm}$ long, were collected from 33 individual sites ( 8 to 10 cores per site) belonging to 21 cooling units along the ChVF and SSC (Fig. 1b). Cores were cut into 22-mm-long standard specimens.
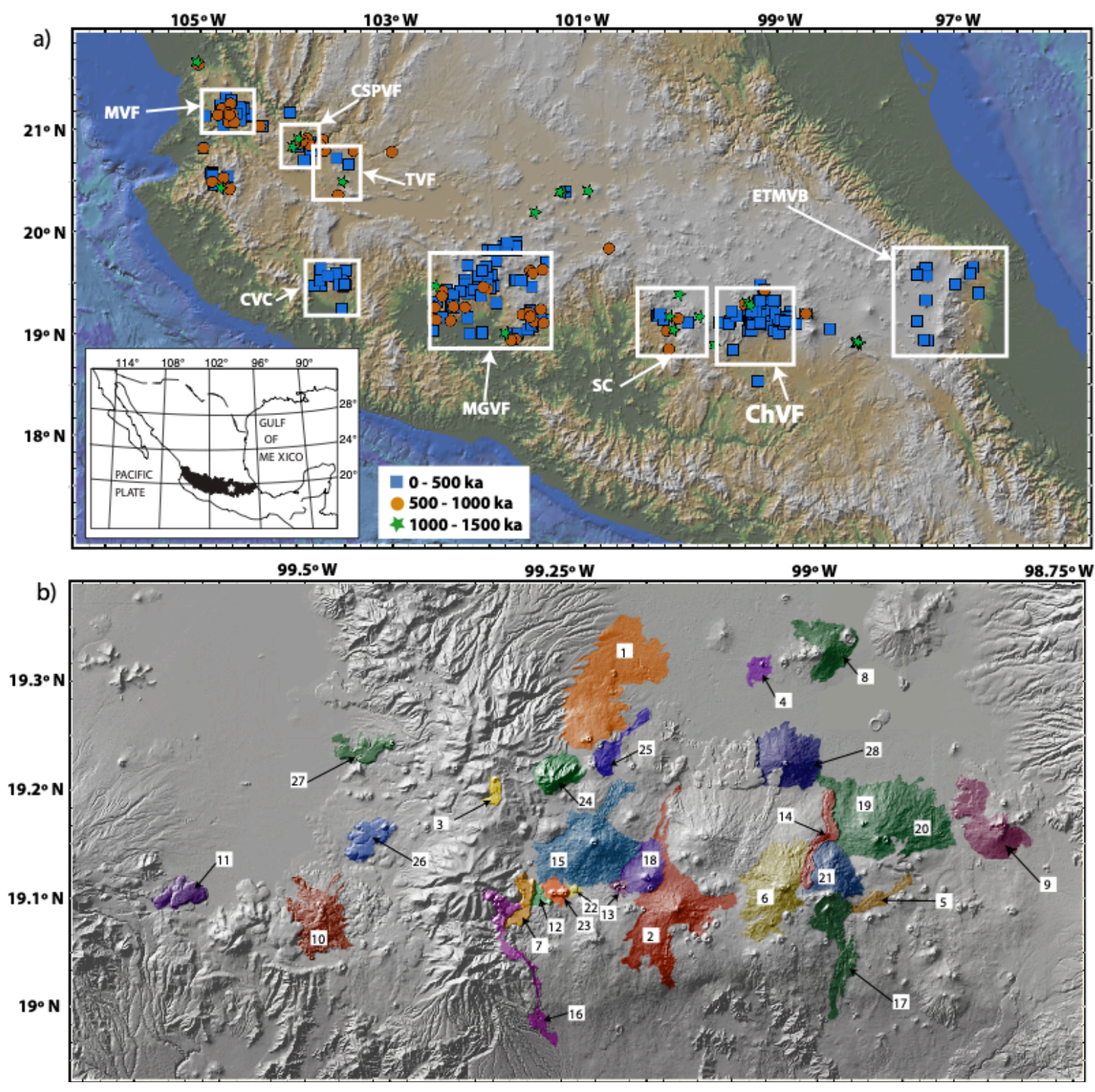

Fig. 1: a) TMVB and location of published paleomagnetic data for the past $1.5 \mathrm{Ma}$ (Satellite image from Google-earth 2018; ChVF: Sierra de Chichinautzin Volcanic Field; CSPVF: Ceboruco-San Pedro Volcanic Field; CVC: Colima Volcanic Complex; ETMVB: Eastern Trans Mexican Volcanic Belt; MGVF: Michoacán-Guanajuato Volcanic Field; MVF: Mascota Volcanic Field; SC: Sierra de las Cruces; TVF: Tequila Volcanic Field). Age references and site locations are available in Table 1S. b) Colored areas represent the sampled cooling units in Sierra de Chichinautzin volcanic field and Sierra de Santa Catarina monogenetic volcanic group (numbers refer to the ID of Table 1, location of the sampling sites and age references are available in Table 2; cooling units 4 and 8 belong to the Sierra de Santa Catarina (SSC) volcanic group). 


\begin{tabular}{|c|c|c|c|c|c|c|}
\hline ID & Cooling unit & $\begin{array}{c}\text { Calibrated } \\
\text { Age (kyrs BP) } \\
\end{array}$ & $\begin{array}{c}\text { Age error } \\
\text { (kyrs) }\end{array}$ & $\begin{array}{c}\text { Age } \\
\text { Method }\end{array}$ & $\begin{array}{c}\text { Uncalibrated } \\
{ }^{14} \mathrm{C} \text { (yrs BP) } \\
\end{array}$ & Reference \\
\hline 1 & Xitle & 1.61 & 0.09 & ${ }^{14} \mathrm{C}$ & $1670 \pm 35$ & Siebe (2000) \\
\hline 2 & Chichinautzin & 1.75 & 0.13 & ${ }^{14} \mathrm{C}$ & $1835 \pm 55$ & Siebe et al. (2004b) \\
\hline 3 & Jumento & 1.97 & 0.08 & ${ }^{14} \mathrm{C}$ & $2010 \pm 30$ & Arce et al. (2015) \\
\hline 4 & Guadalupe & 2 & 0.56 & Ar-Ar & & Jaimes-Viera et al. (2018) \\
\hline 5 & Pelagatos & 2.6 & 0.2 & ${ }^{14} \mathrm{C}$ & $2520 \pm 105$ & Guilbaud et al. (2009) \\
\hline 6 & Tláloc & 7.1 & 0.2 & ${ }^{14} \mathrm{C}$ & $6200 \pm 85$ & Siebe et al. (2005) \\
\hline 7 & Tabaquillo & 7 & 9 & Ar-Ar & & Jaimes-Viera et al. (2018) \\
\hline 8 & Mazatepec & 23 & 4 & Ar-Ar & & Jaimes-Viera et al. (2018) \\
\hline 9 & Chinconquiat & $>31$ & & Stratigraphy & & \\
\hline 10 & Tres Cruces & 9.4 & 0.3 & ${ }^{14} \mathrm{C}$ & $\begin{array}{r}8390 \pm 100 \\
8490 \pm 90 \\
\end{array}$ & Bloomfield (1975) \\
\hline 11 & Tenango Basalt & 9.5 & 1.0 & ${ }^{14} \mathrm{C}$ & $\begin{array}{c}8390 \pm 130 \\
8440 \pm 40 \\
8700 \pm 180 \\
\end{array}$ & Bloomfield (1974) \\
\hline 12 & Los Cardos & $<10$ & & Stratigraphy & & \\
\hline 13 & Cima & 10.1 & 0.6 & ${ }^{14} \mathrm{C}$ & $\begin{array}{r}10160 \pm 210 \\
10410 \pm 80 \\
\end{array}$ & Kirianov et al. (1990) \\
\hline 14 & Tlacotenco & $6.2-14$ & & Stratigraphy & & Siebe et al. (2005) \\
\hline 15 & El Pelado & 10.8 & 0.6 & ${ }^{14} \mathrm{C}$ & $\begin{array}{c}9620 \pm 160 \\
10270 \pm 190 \\
10900 \pm 280 \\
\end{array}$ & Siebe et al. (2004b) \\
\hline 16 & Huilote & $>10$ & & Stratigraphy & & \\
\hline 17 & Cerro del Agua & 12.6 & 0.7 & ${ }^{14} \mathrm{C}$ & $10845 \pm 290$ & Guilbaud et al. (2015) \\
\hline 18 & Acopiaxco & $>14$ & & Stratigraphy & & Lorenzo-Merino (2016) \\
\hline 19 & Dos Cerros 1 & 16.6 & 0.4 & ${ }^{14} \mathrm{C}$ & $13695 \pm 110$ & Guilbaud et al. (2015) \\
\hline 20 & Dos Cerros 2 & 16.6 & 0.6 & ${ }^{14} \mathrm{C}$ & $13769 \pm 201$ & Guilbaud et al. (2015) \\
\hline 21 & Cilcuayo & $>18.7$ & & Stratigraphy & & \\
\hline 22 & Raices-Cajete & 18.9 & 0.3 & ${ }^{14} \mathrm{C}$ & & Mahgoub et al. (2019) \\
\hline 23 & Tres Cumbres & 21.5 & 1.8 & ${ }^{14} \mathrm{C}$ & $\begin{array}{c}16700 \pm 150 \\
19680 \pm 120 \\
\end{array}$ & Kirianov et al. (1990) \\
\hline 24 & Ajusco 1 & 390 & 160 & $\mathrm{~K}-\mathrm{Ar}$ & & Mora-Alvarez et al. (1991) \\
\hline 25 & Ajusco 2 & 22.6 & 0.3 & ${ }^{14} \mathrm{C}$ & $18680 \pm 120$ & Urrutia-Fucugauchi \& Martin del Pozzo (1993) \\
\hline 26 & Malinale 1 & 22.8 & 1.4 & ${ }^{14} \mathrm{C}$ & $18900 \pm 600$ & Kirianov et al. (1990) \\
\hline 27 & Cuautl & 23.5 & 0.5 & ${ }^{14} \mathrm{C}$ & $19530 \pm 160$ & Bloomfield (1975) \\
\hline 28 & Tezontle & 26.3 & 0.8 & ${ }^{14} \mathrm{C}$ & $\begin{array}{l}21860 \pm 540 \\
21860 \pm 540\end{array}$ & Bloomfield (1975) \\
\hline 29 & Teuhtli & 36 & 1.8 & ${ }^{14} \mathrm{C}$ & $31790 \pm 755$ & Guilbaud et al. (2015) \\
\hline 30 & Pueblo Viejo & 80 & 20 & Ar-Ar & & Arce et al. (2013) \\
\hline 31 & Palpan & 260 & 20 & Ar-Ar & & Arce et al. (2013) \\
\hline 32 & Atlacholoaya & 1020 & 160 & Ar-Ar & & Arce et al. (2013) \\
\hline 33 & Villa Guerrero & 1200 & 50 & $\mathrm{Ar}-\mathrm{Ar}$ & & Arce et al. (2013) \\
\hline
\end{tabular}

Table 1. Summary of the reported ages for ChVF and SSC, including the estimated calibrated age. The radiocarbon ages were calibrated with IntCal13 curve (Reimer et al., 2013) using ChronoModel software (Lanos \& Philippe, 2017). The average age (given in kyrs BP) and its error were defined between the older and younger boundaries of the calibrated date interval at $95 \%$ of confidence $(2 \sigma)$. 


\section{Methodology and laboratory procedures}

Rock magnetic experiments were carried out in the Laboratory of Paleomagnetism at UNAM, Mexico (except when indicated) to identify the magnetic carriers of magnetization, estimate the thermal stability of the ferromagnetic minerals during the heating processes, and characterize the domain state of the magnetic particles.

One sample per cooling unit was selected to measure the $k-T$ curves using MFK-FA and MFK2 susceptibility-meters (Agico, Kappabridge) in UNAM and CEREGE laboratories respectively. Specimens were heated in air from room temperature up to $620^{\circ} \mathrm{C}$. In order to further investigate the ferromagnetic mineralogy, the hysteresis loops and acquisition of isothermal remanent magnetization (IRM) curves were acquired on small chip rocks from one sample per cooling unit using a Princeton 2900 MicroMag Alternating Gradient Magnetometer, with maximum applied fields up to 1.2 Tesla.

For the determination of the paleomagnetic directions from the ChVF and SSC, 33 individual sites from 21 different cooling units were studied. Remanent magnetizations were measured using an AGICO JR-6 spinner magnetometer in a magnetically shielded room and analyzed by stepwise alternating field (AF) and/or thermal demagnetization on specimens from all sites. AF demagnetization was carried out on 183 specimens with a Molspin demagnetizer (Molspin Limited, England), using 10 steps up to $100 \mathrm{mT}$. Thermal demagnetization was performed on 79 specimens in a non-inductive Schönstedt furnace, with $10-12$ steps every $40^{\circ} \mathrm{C}$ from $100^{\circ} \mathrm{C}$ to $600^{\circ} \mathrm{C}$.

The directions of the Characteristic Remanent Magnetization (ChRM) were estimated by principal component analysis (Kirschvink, 1980), with at least 5 demagnetization steps and a maximum angular deviation (MAD) below $5^{\circ}$. As there are no report of field evidences for local tectonic movements posterior to the lava emplacement, no tectonic correction was applied.

Mean directions and VGPs were calculated at each site with Fisher statistics (Fisher, 1953) and summarized in Table 2 with their $\alpha 95$-confidence circle and Fisher precision parameter (k) parameters. A constant VGP latitude of $45^{\circ}$ was used as a cutoff to discriminate the transitional values (Tauxe et al., 2003; Johnson et al., 2008; Doubrovine et al., 2019).

\section{Rock magnetism}

\subsection{Susceptibility as a function of temperature $(k-T)$}

After the $k-T$ experiments, up to $70 \%$ of the curves display two magnetic phases during the heating process and high reversibility (Fig. 2a) or a higher susceptibility for the cooling branch.

The Curie temperature range is between $510^{\circ} \mathrm{C}$ and $540^{\circ} \mathrm{C}$ for the high-temperature phase corresponding to Ti-poor titanomagnetite. The Curie temperature ranging from $230^{\circ} \mathrm{C}$ to $300^{\circ} \mathrm{C}$, the low-temperature phase, is likely Ti-rich titanomagnetite. Two samples show highly reversible curves observed with the unique presence of Ti-poor magnetite (Fig. $2 \mathrm{c}$ and 2d). The irreversible curve of El Pelado (Fig. 2b) might be related to the occurrence of Timaghemite instead of Ti-magnetite, associated to mineral alteration during the heatingcooling process in the laboratory. 

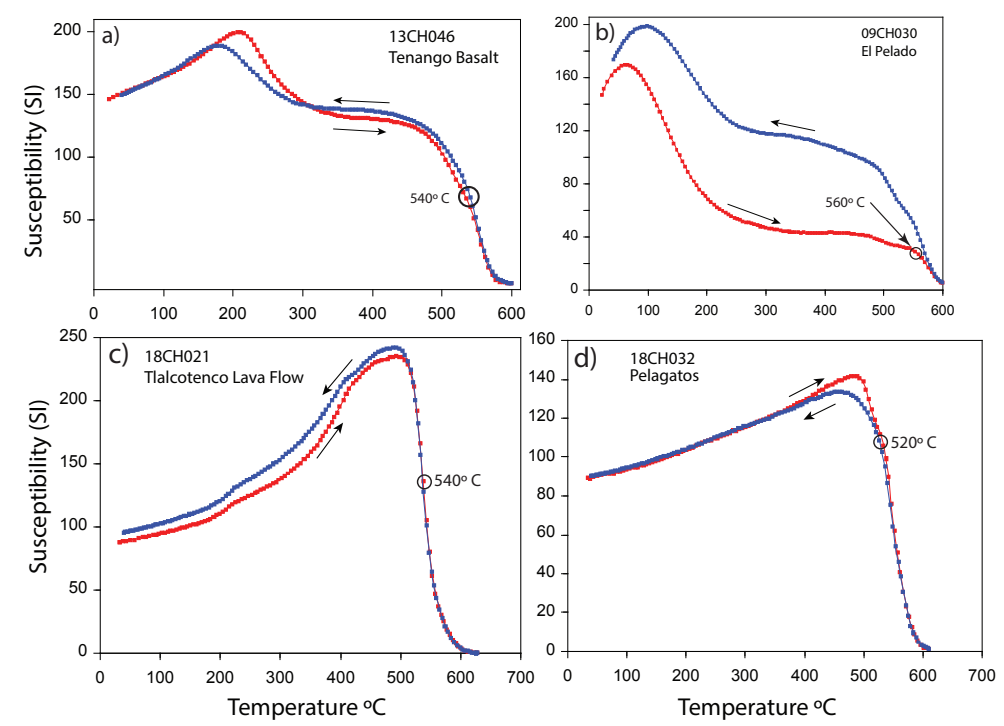

Fig. 2. Representative heating (red) and cooling (blue) susceptibility vs. temperature curves.

\subsection{Hysteresis and IRM curves}

The determination of saturation magnetization $\left(\mathrm{M}_{\mathrm{s}}\right)$, saturation remanent magnetization $\left(\mathrm{M}_{\mathrm{rs}}\right)$, coercive force $\left(\mathrm{H}_{\mathrm{c}}\right)$ and remanent coercive force $\left(\mathrm{H}_{\mathrm{cr}}\right)$ gave information on the domain state of the magnetic grains. With Mrs/Ms ratios between 0.1 and 0.6 , and $\mathrm{H}_{\mathrm{cr}} / \mathrm{H}_{\mathrm{c}}$ between 1.2 and 4.0. $80 \%$ of the samples, fit in the pseudo single domain (PSD) field of the Day plot (Day et al., 1977), likely indicating a mixture of single domain (SD) and multidomain (MD) grains (Fig. 3b), also evidenced by the wasp-waisted shape of the 09CH007 sample (Fig 3a). Hysteresis and IRM curves reach saturation above $800 \mathrm{mT}$, which is consistent with the presence of magnetite with different contents of titanium and the absence of high-coercivity minerals (Fig. 3).

Samples from El Pelado and Chichinautzin volcano cooling units are close to SD field and those of Tenango basalt and Palpan cone to MD field.

a)
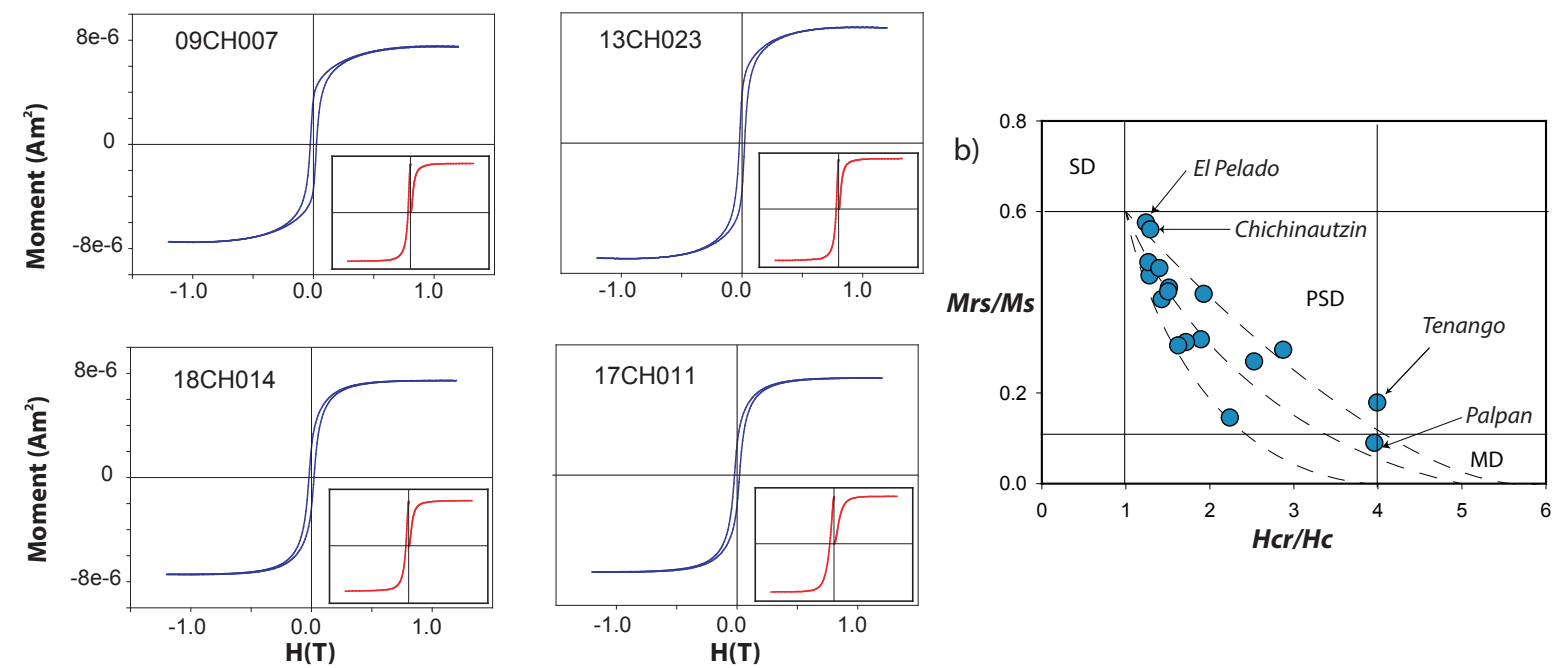

Fig. 3. a) Representative hysteresis plots in blue and IRM acquisition and backfield curves in red. Paramagnetic components are removed. b) Day plot from ChVF and SSC samples with SD-MD mixing curves of Dunlop (2002). 


\section{Directional analysis}

We obtained 33 new site directions from ChVF and SSC monogenetic volcanic group: 32 sites are of normal polarity, and one (Villa Guerrero) of reverse polarity (Figure 5a) with an age at $1200 \pm 50 \mathrm{ka}$ (Arce et al., 2013), consistent with the Matuyama chron. This is the first reversed polarity reported from the ChVF. After AF and thermal demagnetization, $80 \%$ of the samples present a single component of magnetization (Fig 4a-b). The rest of the samples show a secondary component, probably of viscous origin, that could be removed at low field (less than $20 \mathrm{mT}$; Figure $4 \mathrm{c}-\mathrm{d}$ ) or low temperature (less than $200^{\circ} \mathrm{C}$; Figure $4 \mathrm{e}-\mathrm{f}$ ). As mentioned before, no structural correction was applied to the samples, as no recent rotation or tectonic displacements were seen in the field or reported in the area in previous published studies (e.g. Herrero, 1977; Urrutia et al., 1993).

Values of $\mathrm{k}$ and $\alpha_{95}$ from all sites range from 68 to 1495 and $2.7^{\circ}$ to $8.5^{\circ}$, respectively, underlying the overall high precision and confidence of our mean directions.

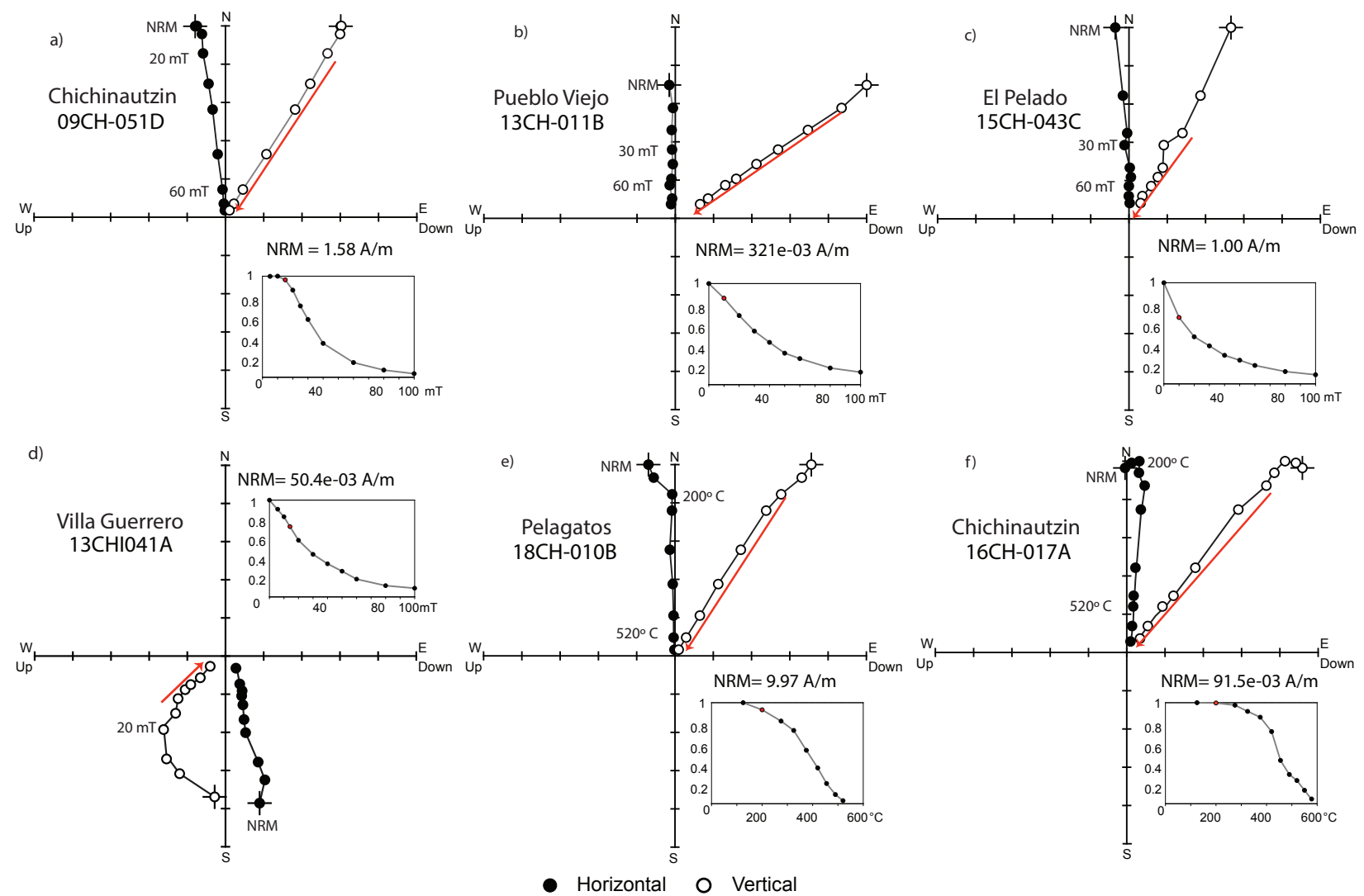

Fig. 4. Representative orthogonal plots and demagnetization curves of AF (a-d) and thermal (e-f) demagnetization. Solid (open) circles are the projection on the horizontal (vertical) plane. Red line indicates the number of points selected for the ChRM calculation.

The cooling units were divided into two groups according to their ages: i) the younger group of 17 out of the 21 sampled cooling units with ages ranging from 1.7 to $40 \mathrm{ka}$, and ii) the older group of 4 out of the 21 cooling units with ages ranging from $80 \mathrm{ka}$ to $1.2 \mathrm{Ma}$. The mean direction associated to the younger group $\left(\mathrm{Dec}=359.7^{\circ}, \mathrm{Inc}=33.1^{\circ}, \mathrm{N}=16, \mathrm{k}=22.8\right.$, $\alpha_{95}=7.1^{\circ}$, Plat $=89.6^{\circ} \mathrm{N}$, Plong $=205.1^{\circ} \mathrm{E}, \mathrm{K}=37.6, \mathrm{~A}_{95}=6.1$ ), is consistent with the direction of the dipole field (at the average site latitude). The precision interval of $\mathrm{K}$ with the $95 \%$ confidence (Cox, 1969) are ranging from $25<\mathrm{K}<50$. For this estimation, one cooling unit (El Pelado) was discarded for the calculation, because it did not fulfill our selection criteria. The mean direction associated to the older group $\left(\mathrm{Dec}=357.9^{\circ}, \mathrm{Inc}=49^{\circ}, \mathrm{N}=4, \mathrm{k}=28.2, \alpha_{95}=19.2\right.$, 
Plat $=73.1^{\circ} \mathrm{N}$, Plong $=253.8^{\circ} \mathrm{E}, \mathrm{K}=38.8, \mathrm{~A}_{95}=23.8$ ) is pretty similar with a scatter likely related to a larger time interval with only four cooling units available. However, the precision interval of $\mathrm{K}$ with the $95 \%$ confidence (Cox, 1969) is ranging from $6<\mathrm{K}<39$, that is statistically indistinguishable with the younger group. The dispersion of the VGP estimated for this study $\left(\mathrm{S}_{\mathrm{b}}=13.4\right)$ fits with the expected value for the latitude (ca. $\left.20^{\circ}\right)$ according with the Model $\mathrm{G}$ (McFadden et al., 1991), and with the projections from different datasets at similar latitudes (e.g. Johnson et al, 2008; Opdyke et al., 2015; Cromwell et al., 2018).

\section{Comparison with previous published data from ChVF}

The ChVF has been previously studied reported by twelve paleomagnetic studies (Herrero-Bervera and Pal, 1977; Urrutia-Fucugauchi and Martin del Pozzo, 1993; Mooser et al., 1994; Gonzalez et al., 1997; Mora-Alvarez et al., 1991; Böhnel et al., 1997; Böhnel and Molina-Garza, 2002; Urrutia-Fucugauchi, 1996; Vlag et al., 2000; Morales et al., 2001; AlvaValdivia, 2005; Maghoub, 2019) for rocks younger than $40 \mathrm{ka}$. One of these papers (Mooser et al., 1994) was not included in the analysis because important information as the sampling location, age and demagnetization protocols were not given in the publication.

A crucial aspect of such a compilation is the quality of the ages attributed to the different data. When possible, the ages given in the original papers were updated (Table 1). Because it was not possible to attribute them a reliable absolute age, the mean results of Ajusco (Morales et al., 2001) and the site CH-45 (Urrutia-Fucugauchi \& Martin Del Pozzo, 1993) had to be discarded. Similar problem occurs with the ages of Acopiaxco and Huilote from Morales et al. (2001), but a relative age could be estimated by stratigraphy according to recent published data, supported by direct observations in the field. Only updated ages by cooling unit are given in Tables 1 and 2.

According to their location and reported age, the previous published mean directions have been allocated to the different ChVF's cooling units (Figure 1b, Table 2). When different publications report data from the same cooling unit, as for Xitle and El Pelado volcanoes, we calculate a mean direction at the cooling unit level (Table 2). For the special case of El Pelado volcano, two means are available: a mean estimated at sample level obtained from 44 samples demagnetized in this study obtained for different locations of the volcano; and a mean calculated at site level from 6 sites reported from previous works in El Pelado, details available in Table 2. For the previous published data, when more than two sites were available for a given $\mathrm{CU}$, the mean was calculated at site level. When only two sites were available no average was provided, such as Cima volcano, with three sites available, but one of them were discarded. All the mean directions estimated for a given cooling units in this study were calculated at sample level. In order to assure similar quality between our data and the previously published paleomagnetic data, we defined some minimum quality criteria: at least 4 specimens are required to obtain a mean direction for each cooling unit, and cut off value for $k$ parameter larger than 60 (e.g. Johnson et al., 2008; Cromwell et al., 2018). This value was determined from the statistical analysis of the directional data compilation from the TMVB on the past $1.5 \mathrm{Ma}$ (Fig. 6) and approaching within $95 \%$ confidence of the distribution of the data (ca. $2 \sigma$ ).

A special case is the Tenango basalt, located on the western side of the ChVF, of $8.5 \pm 0.16 \mathrm{ka}$ (Bloomfield, 1974), that presents high value of inclination $\left(68.2^{\circ}\right)$, atypical for this period and at this latitude. Gonzalez et al. (1997) report a similar value for the Tezontle volcano $(21.8 \pm 38 \mathrm{Ka}$, Bloomfield, 1975), located at the southwestern part of the ChVF. Finally, other two cooling units present similar high inclination values: Pueblo Viejo lava 
flow and Atlacholoaya scoria cone, both cooling units being located at the southwestern boundary of the volcanic field, but belonging to the older group of the ChVF $>40 \mathrm{ka}$ (Arce et al., 2013). On the other side, the cooling unit Tláloc, $7.1 \pm 0.2 \mathrm{ka}$, and the Tlalcotenco lava flow, 6.4-14 ka, (Siebe, el al., 2005) present atypical low inclination value of $10^{\circ}$ and $7^{\circ}$ respectively (Table 2). None of these directions can be considered as transitional because they are inside the $45^{\circ}$ cutoff (Johnson et al., 2008; Cromwell et al., 2018) to differentiate transitional polarities (Figure 5b). According to the statistical quality of the mean directions, there is no objective reason to discard these sites, and they have been included in the mean calculations.

All selected mean directions per cooling unit are presented with their $\alpha_{95}$ confidence circle in Figure 5a, and the associated VGP's in Figure 5b. An overall mean was estimated for the last $40 \mathrm{ka}\left(\mathrm{Dec}=359.1^{\circ}, \mathrm{Inc}=34.1^{\circ}, \mathrm{N}=30, \mathrm{k}=22.2, \alpha_{95}=5.7^{\circ}, \mathrm{Plat}=88.6^{\circ} \mathrm{N}\right.$, Plong $=208.6^{\circ} \mathrm{E}, \mathrm{K}=32.4, \mathrm{~A}_{95}=4.7^{\circ}$ ). This average is similar to the mean direction that was calculated with our samples, and consistent with the expected value of the actual dipole. The 33 available cooling units for the ChVF and SSC were used to calculate the mean for the last $1.5 \mathrm{Ma}\left(\mathrm{Dec}=359.1^{\circ}, \mathrm{Inc}=35.3^{\circ}, \mathrm{N}=33, \mathrm{k}=21.6, \alpha_{95}=5.5^{\circ}, \mathrm{Plat}=87.7^{\circ} \mathrm{N}\right.$, Plong $=227.4^{\circ} \mathrm{E}$, $\mathrm{K}=31.8, \mathrm{~A}_{95}=4.5^{\circ}$ ) that remains very close to the geographic pole. The overall dispersion of the VGP's estimated $\left(\mathrm{S}_{\mathrm{b}}=14.37\right)$ of the previous published data combined with the new dataset from this study match (Figure 8) with the predicted value of the Model G (McFadden, et al., 1991) and with the curves of latitude dependence of VGP scatter published recently (e.g. Johnson et al, 2008; Opdyke, et al., 2015; Cromwell, et al., 2018), showing an accurately average secular variation recorded from the ChVF lavas.

Table 2. Summary of the directional results, where $\mathrm{N}$ is the number of specimens used for the calculation of the mean direction at the site level or the number of sites used for the calculation of the mean direction of the cooling unit, when there is more than six sites in a cooling unit.; References: TS, This study 1) Herrero-Bervera and Pal, 1977, 2) UrrutiaFucugauchi and Martin Del Pozzo, 1993; 3) González et al., 1997; 4) Böhnel and MolinaGarza, 2002, 5) Morales et al., 2001; 6) Alva-Valdivia, 2005; 7) Vlag et al., 2000; 8) UrrutiaFucugauchi, 1996; 9) Böhnel et al., 1997; 10) Mahgoub et al., 2019; 11) Mora-Alvarez et al., 1991.

+ Mean direction estimated at site level.

* Sites that do not fulfill our selection criteria were discarded for the calculation of mean directions. 


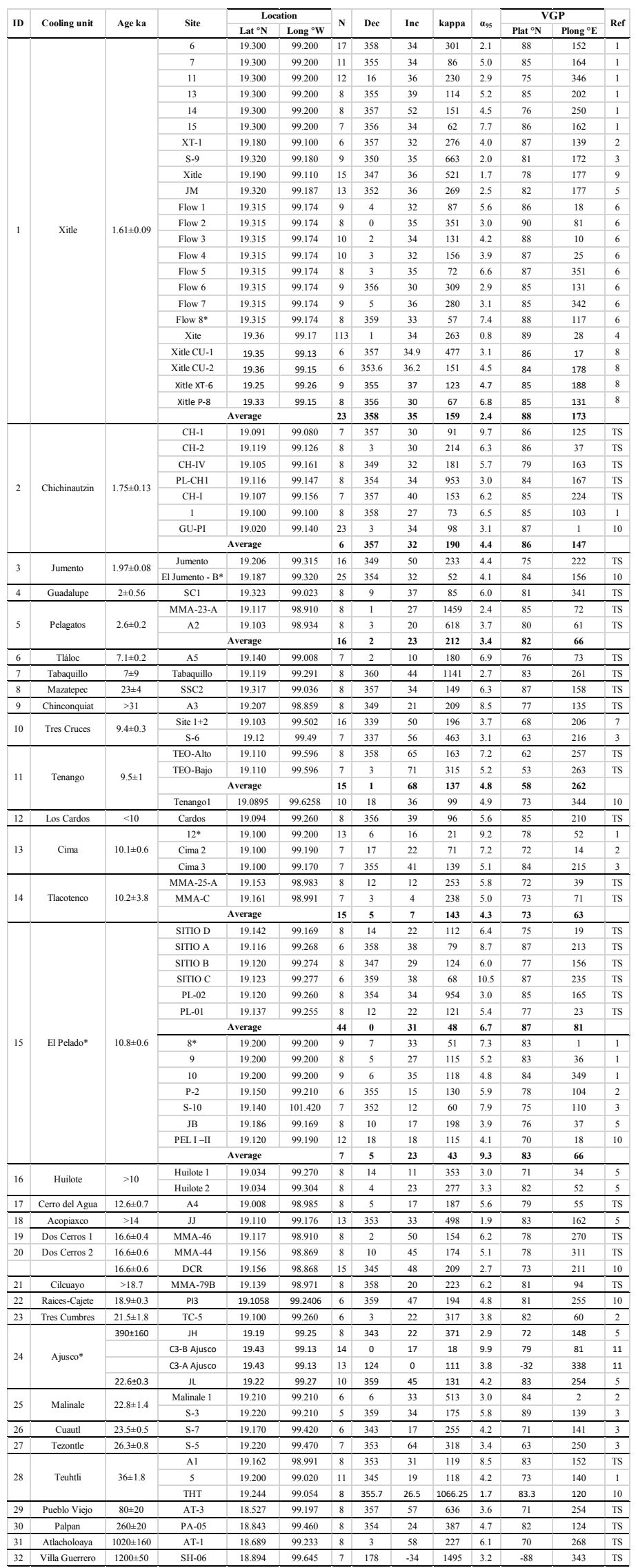




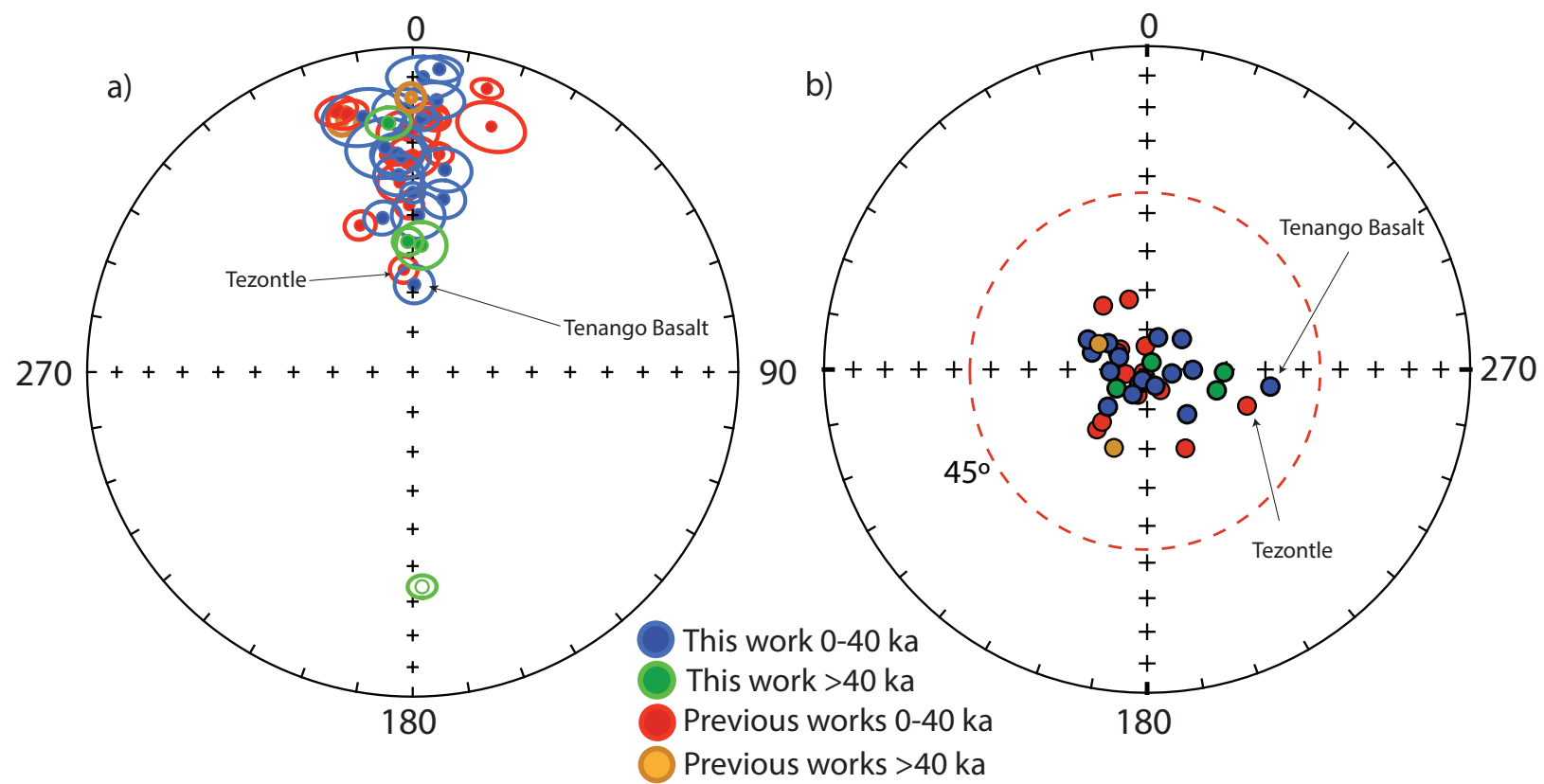

Fig. 5. Equal area projection of the mean directions (left) and distribution of the VGP's (right) per cooling unit of the ChVF.

\section{The TMVB paleomagnetic dataset and the time averaged dipole field for the last 1.5 Ma}

The Trans Mexican volcanic belt has been active since the last $12 \mathrm{Ma}$. However, we restricted our compilation to the last $1.5 \mathrm{Ma}$, the period for which we have most of the paleomagnetic studies. 48 publications (Table 1S) were retrieved for this period, most of them are fairly recent ( $72 \%$ of the articles were published in the 2000 s), and only a few were published in the 1970s. 30\% of the data have an age lower than $50 \mathrm{ka}, 20 \%$ of the data have ages between 50-250 ka, and no trend can be seen between the age distribution and the location (Table 1S).

Around $70 \%$ of the previous paleomagnetic data come from the central part of the TMVB: Michoacán-Guanajuato volcanic field (MGVF); Sierra de la Cruces (SC); and ChVF (Figure 1b). The latitudes of the data are fairly similar (between $18.2^{\circ} \mathrm{N}$ and $21.7^{\circ} \mathrm{N}$ ), but the longitudes vary a lot more (from $96.5^{\circ} \mathrm{W}$ to $106^{\circ} \mathrm{W}$ ) covering about $1000 \mathrm{~km}$ from east to west. Therefore, to consider these differences in longitude (up to $10^{\circ}$ ), all compiled directions (Table 1S) were relocated to a common geographic place, arbitrarily chosen at Zócalo downtown in Mexico City $\left(19.4327^{\circ} \mathrm{N}\right.$ and $\left.99.1332^{\circ} \mathrm{W}\right)$.

Altogether 439 individual sites were compiled (Figure 6b, Table 1S). All data that have been identified by the original authors as remagnetized units, affected by lightning or local tectonics and displaced blocks, or were not considered in the analysis, and are labelled as disturbed in Table 1S. Using a $45^{\circ}$ cut off for transitional VGP's, some other data (labelled as transitional in Table 1S) were also discarded. The same care was paid to the age of the determination and a certain number of the data were discarded because of imprecision or absence of age (labelled as age in Table 1S). After applying these three basic criteria, ca. 29\% of the data (Figure 6c) were removed. Finally, the quality criteria used to select the ChVF data $(\mathrm{N} \geq 4$ and $k>60$ ) were applied to the TMVB data (Figure 6d). The distribution of $k$ in the published data is summarized in Figure 6e, with $29 \%$ of the data below the chosen value of 
$60,61 \%$ of the data having $k$ ranging from 60 to 300 , and $9 \%$ of the data with very highquality value over 300 .

An overall mean direction and pole were estimated with the selected paleomagnetic dataset, including the new results from ChVF and SSC. Mean directions were estimated for both normal and reverse polarities, $\left(\mathrm{Dec}=358.4^{\circ}, \mathrm{Inc}=35^{\circ}, \mathrm{N}=245, \mathrm{k}=31.7, \alpha_{95}=1.5^{\circ}\right)$ and $\left(\mathrm{Dec}=180.6^{\circ}, \mathrm{Inc}=-30.1^{\circ}, \mathrm{N}=25, \mathrm{k}=32.5, \alpha_{95}=5.2^{\circ}\right)$ respectively. The reversal test $(\mathrm{McFadden}$ and McElhinny, 1990) is positive with a difference of $\sim 3^{\circ}$ between the reversal and normal polarities, supporting the reliability of the selected dataset. The combined mean direction, calculated for the past $1.5 \mathrm{Ma}$ of the TMVB $\left(\mathrm{Dec}=358.4^{\circ}, \mathrm{Inc}=35^{\circ}, \mathrm{N}=275, \mathrm{k}=31.7\right.$, $\alpha_{95}=1.6^{\circ}$ ) with its corresponding VGP (Plat $=88.3^{\circ} \mathrm{N}$, Plong $=188.6^{\circ} \mathrm{E}, \mathrm{K}=40.2, \mathrm{~A}_{95}=1.4^{\circ}$ ), is therefore very robust and strongly support the reliability of the Geocentric Axial Dipole hypothesis.

Mexico is indeed characterized by a very active tectonic setting, especially on the west coast with the subduction of the Cocos Plate beneath the North American Plate along the Acapulco trench. The tectonics activity, considered active in the present days make possible local displacements and vertical axis rotations (e.g. Alva-Valdivia et al., 2017; Alva-Valdivia et al., 2019), with low influence in the general setting of all the TMVB. However, if this active tectonic was clearly the trigger of the volcanic activity in central México (GomezTuena et al., 2007), no large movement that would have disturbed the TMVB directions could be detected, at least for the last $1.5 \mathrm{Ma}$. The major tectonic movements along the TMVB were reported for the older activity during the Miocene (Alva-Valdivia et al., 2000). It is possible that for the younger activity some areas could be affected by regional tectonic activity, generating tilts and/or vertical axis rotations, the data reported from the authors as tectonically disturbed were no considered for this study. The unrecognized tectonic activity in the area that was not reported by the authors is not possible to observe directly, but the accuracy and precision of the date is supported by the statistical parameters published. The paleosecular variation (PSV) recorded by the volcanic rocks of the TMVB show that latitude dependence of dispersion of the combined polarities of the VGP's estimated for all the dataset in this work $\left(\mathrm{S}_{\mathrm{b}}=14.6\right)$, show that matches with the different models (e.g. Johnson et al, 2008; Opdyke, et al., 2015; Cromwell, et al., 2018) at the mean latitude of the TMVB (ca. 20 ${ }^{\circ}$ ). After discarding the disturbed data from the selection criteria, is possible to determine that the TMVB has a reliable record of the PSV for the last 1.5 Ma. The dispersion of the VGP's show that the local tectonic activity doesn't affect considerably to the mean values estimated in this study (Figure 8). As reported by Opdyke, et al. (2015), results from lower latitudes show disturbances on the $S_{b}$ due to the intense activity recorded.

Looking at the evolution of relocated declination and inclination through time, we can see that the Brunhes normal chron (0-781 ka) is well recorded in the TMVB dataset (Figure $7 \mathrm{a})$. It is not the same for the Matuyama reverse chron (781-2581 ka), especially during the first reverse subchron (C1r.1r, 781-988 ka) that presents almost as many normal polarity data as reverse polarity data (Figure 7a). Part of this dispersion is probably due to age uncertainty, but may also be related to undetected remagnetizations in a recent normal field. While the Jaramillo subchron (988-1072 ka) is accurately recorded, the Cobb subchron (1173-1185 ka) is not represented in the TMVB dataset. 

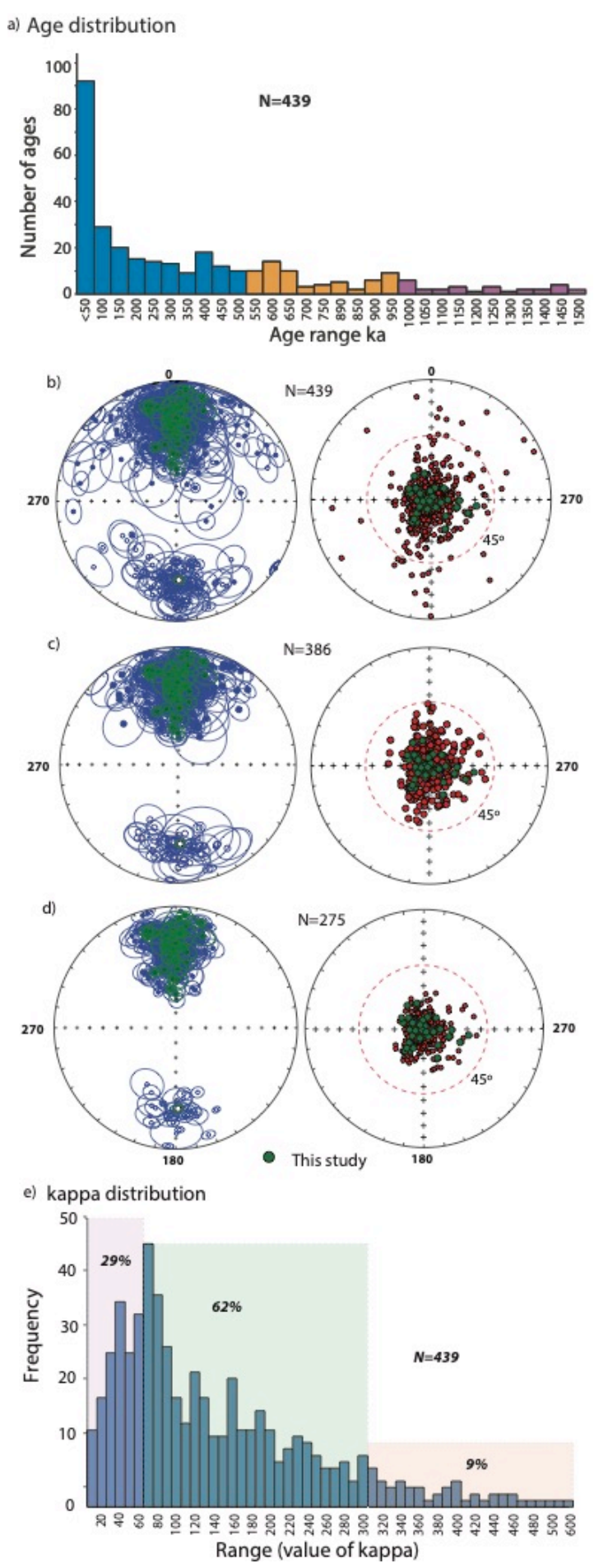

Fig. 6. Directional relocated data and VGP. a) Age distribution; b) all the data in the compilation; c) after removing data disturbed, transitional or with age problem; d) after applying quality criteria; e) distribution of $k$ for the paleomagnetic directions of the TMVB for the last 1.5 Ma. Full dataset available in Table 1S. 


\section{Secular variation recorded in the TMVB}

Considering the limitations of the available dataset, we concentrate on a more recent period, for which we have the larger number of studies, ca. 34\% of the full dataset compiled to study the secular variation: the last 14 millennia (Figure $7 \mathrm{~b}$ ).

For the last 4 millennia, the TMVB results are consistent with the predictions at Mexico City of two recent global models: CALS10k2 (Constable, et al., 2016) and SHA.DIF.14k (Pavón-Carrasco, et al., 2014). This result is not surprising as most data considered in this analysis were included in the calculation of these models. During the last four millennia, declination varied between $-20^{\circ}$ and $20^{\circ}$ and inclination varied between 15 and $60^{\circ}$.

For earlier periods, the gaps in the database, especially between 5000 and $8000 \mathrm{BP}$ and beyond $11000 \mathrm{BP}$, prevent an accurate recovery of the secular variation. The range of directions between 9000 and 11000 BP suggests a larger and faster secular variation than predicted by the global models. High inclination values up to $68^{\circ}$ and low declination values up to $-30^{\circ}$ were observed in Tenango, la Taza and Tres Cruces cooling units (Figure $7 \mathrm{~b}$ ).

More data are required to better constrain this large variation and understand its geomagnetic origin.

a)

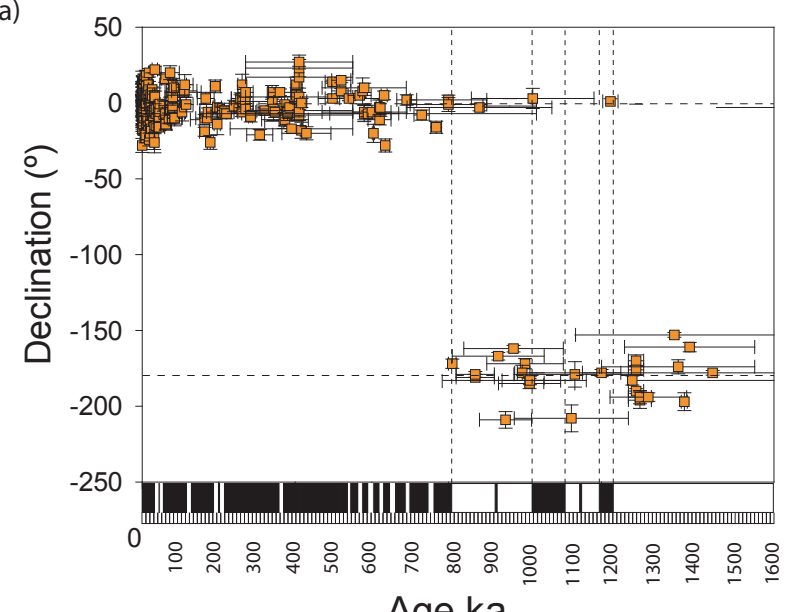

Age ka

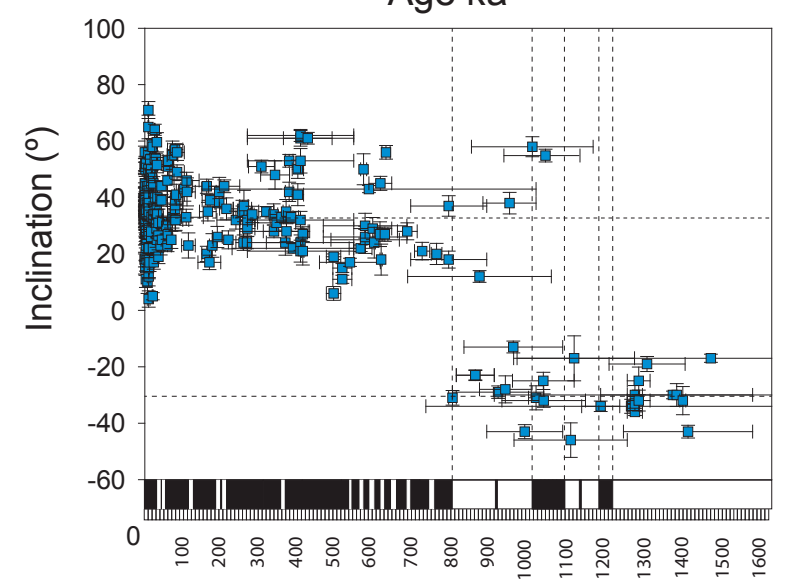

Age ka b)
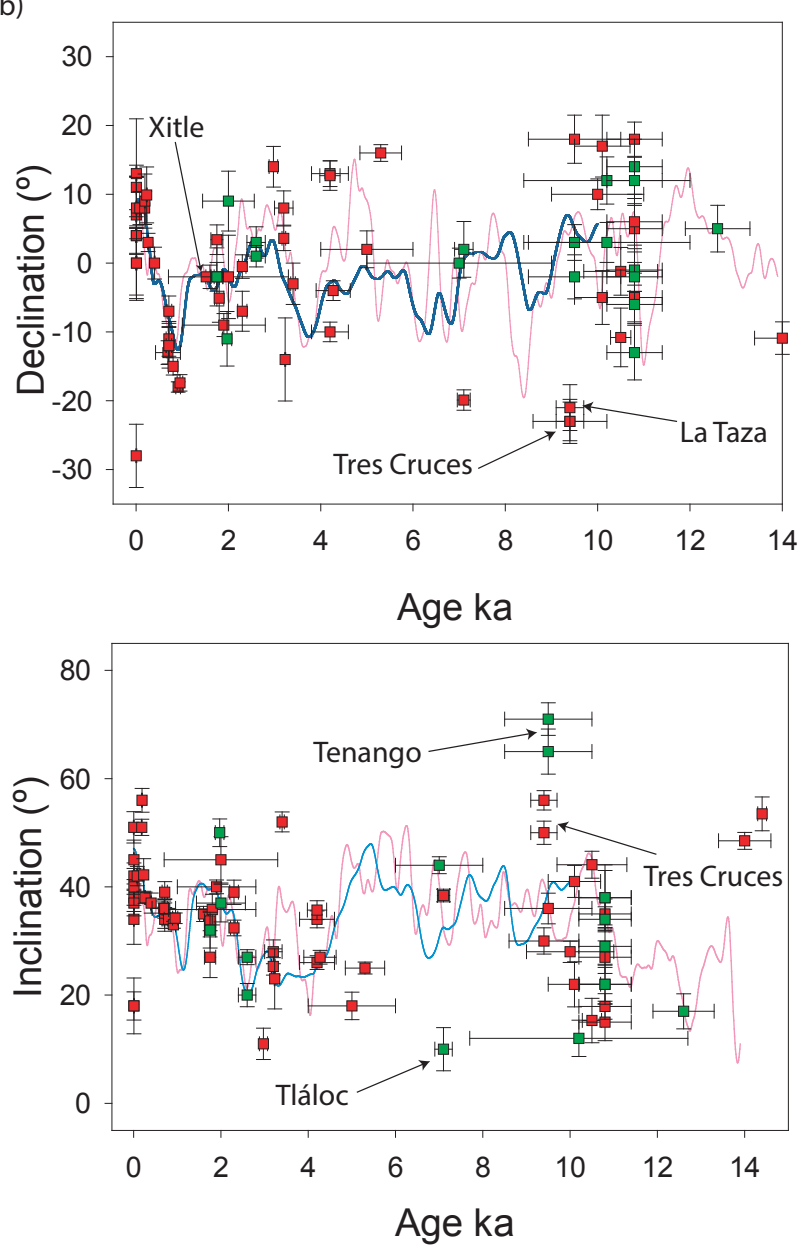

Fig. 7. Distribution of the declination and inclination parameters on the TMVB for the past $1.5 \mathrm{Ma}$ (a). Data from the past $14 \mathrm{ka}$ with the models SHA.DIF.14k and CALS10k2 (b). 


\subsection{Dispersion of the VGP's}

During the last years, different compilations of directional data from different latitudes around the world, including Mexico were performed (e.g. Johnson, et al., 2008; Opdyke, et al., 2015; Cromwell, et al, 2018, Doubrovine, et al., 2019). The objective is to assembly the record of the PSV at different intervals of time at different latitudes, showing the dependence of the dispersion of the VGP scatter with the latitude. In this work the dispersion of the VGP was estimated for the ChVF data, and for the dataset compiled for the TMVB, to verify the record of the concordance with the Model G (McFadden, et al., 1991) and with the compilations proposed for the past 0-5 Ma and 0-10 Ma. For Mexico, with a latitude ca. $20^{\circ}$, different works estimate the PSV by the VGP scatter for 0 to 5 Ma. Mejia et al. (2005) estimate the VGP scatter $\left(\mathrm{S}_{b}=12.7^{\circ}\right)$ for the TMVB by selecting 187 sites, and found equivalence with the expected value from Model $\mathrm{G}\left(\mathrm{S}_{\mathrm{b}}=13.5^{\circ}\right)$. Later, Ruiz-Martinez, et al. (2010) with 77 selected sites, estimated the dispersion of the VGP $\left(\mathrm{S}_{\mathrm{F}}=14.8^{\circ}\right)$ and compared the fit with the Model $\mathrm{G}$ and the model that use a dataset from Mexico $\left(\mathrm{S}_{\mathrm{b}}=14.3\right)$ proposed by Johnson et al. (2008). In this study, we compare the VGP scatter estimated for ChVF $\left(S_{b}=14.4\right)$ and for the entire compilation of TMVB $\left(S_{b}=14.6\right)$, with the results of three global compilations that uses different results from Mexico from 0 to $5 \mathrm{Ma}$ and from 0 to $10 \mathrm{Ma}$ (Cromwell et al, 2018). Figure 8 shows the correspondence of the results from this study with the expected values according with the three models. In the case of Cromwell et al. (2018), is possible to observe a slight lower $\mathrm{S}_{\mathrm{b}}$ value, in comparison with the results from the TMVB. This small difference could be associated to a higher average of the model (0-10 Ma). However, in all cases, the results estimated for ChVF and TMVB fit with the expected value of the $\mathrm{S}_{\mathrm{b}}$ according to the latitude. This concurrence, supports the hypothesis that the local tectonic activity in the TMVB does not affect significantly the average estimated for the last $1.5 \mathrm{Ma}$.

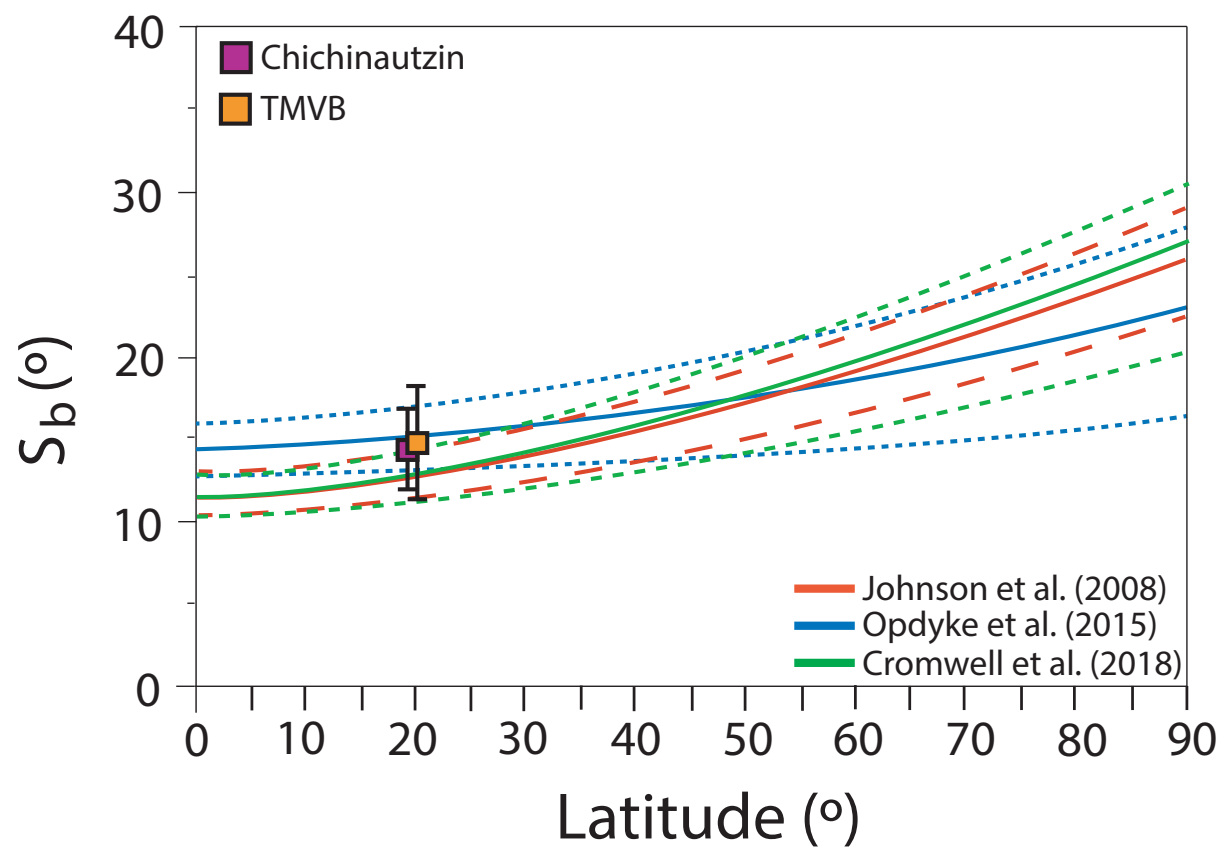

Figure 8. Latitude dependence of the VGP's for the last $5 \mathrm{Ma}$ (Johnson, et al., 2008 and Opdyke, et al., 2015) and for the last $10 \mathrm{Ma}$ (Cromwell, et al. 2018). Modified from, Doubrovine, et al. (2019). 


\section{Conclusions}

The ferromagnetic mineralogy of the ChVF and SSC volcanic groups is dominated by titanomagnetite with different contents in titanium and Curie temperatures ranging from $230^{\circ} \mathrm{C}$ to $540^{\circ} \mathrm{C}$. The magnetic domain state is a mixture of single and multidomain grains.

The directional analysis of the cooling units shows that the mean direction and VGP obtained for the last $40 \mathrm{ka}$ for ChVF are: $\left(\mathrm{Dec}=359.1^{\circ}, \mathrm{Inc}=34.1^{\circ}, \mathrm{N}=30, \mathrm{k}=22.2, \alpha 95=5.7^{\circ}\right)$; and $\left(\mathrm{Plat}=88.6^{\circ} \mathrm{N}\right.$, Plong $=208.6^{\circ} \mathrm{E}, \mathrm{K}=32.4, \mathrm{~A}_{95}=4.7^{\circ}$ ) respectively. These values are close to the present GAD value. The directional results of this study also fit well with the predictions in Mexico City of the global models SHA.DIF.14k and CALS10k2 but only a few data are available from 5 to $9 \mathrm{ka}$, and study of other structures formed in this time range will be necessary to improve the accuracy of the curves. Similarly, the mean direction and corresponding VGP for the past $1.5 \mathrm{Ma}$ are: $\left(\mathrm{Dec}=359.1^{\circ}, \mathrm{Inc}=35.3^{\circ}, \mathrm{N}=33, \mathrm{k}=21.6\right.$, $\left.\alpha 95=5.5^{\circ}\right)$; and $\left(\mathrm{Plat}=87.7^{\circ} \mathrm{N}\right.$, Plong $\left.=227.4^{\circ} \mathrm{E}, \mathrm{K}=31.8, \mathrm{~A} 95=4.5^{\circ}\right)$, respectively, also consistent with the expected GAD value in this period. A reversed polarity dated at $1020 \pm 160$ (Arce, et al., 2013) was found, and this is the first geomagnetic reversal recorded by the ChVF.

The mean directions from $\mathrm{ChVF}$ and SSC are consistent with the mean directional data recorded in volcanic rocks for all published data from the TMVB $\left(\mathrm{Dec}=358.4^{\circ}\right.$, Inc $=$ $35^{\circ}, \mathrm{N}=275, \mathrm{k}=31.7, \alpha_{95}=1.4^{\circ}$ ) with its corresponding VGP (Plat $=88.3^{\circ} \mathrm{N}$, Plong $=188.6^{\circ} \mathrm{E}$, $\mathrm{K}=40.2, \mathrm{~A}_{95}=1.4^{\circ}$ ). The selection criteria allowed identify the highest quality data to describe the evolution of the time average dipole field, and to constrain the results that will give the most reliable mean directions and VGPs. The directional results and the VGP's scatter (Figure 8) fit with the expected values according with the latitude of the TMVB, proposed by different global compilations (Johnson, et al., 2008; Opdyke, et al., 2015; Cromwell, et al, 2018). The concordance confirms that the TMVB has not been affected considerably by local tectonics in the past $1.5 \mathrm{Ma}$. However, large gaps remain in the temporal record of the TMVB that should be filled by further paleomagnetic studies.

\section{Acknowledgements}

We appreciate the financial support to LMAV from PAPIIT-DGAPA-UNAM IN1 13117 (Mexico), to LMAV and MP from the ANR-CONACyT (France-Mexico) 273564 research projects. GH was supported by Campus France PRESTIGE program (PRESTIGE-2017-10002). Thanks to J. A. González Rangel, M. Espinosa, V. Macias and François Demory for their support in the laboratories. The authors would like to thank Dr. A. Biggin (editor), Dr. P. Doubrovine and an anonymous reviewer for their comments. 


\section{References}

Aguirre-Diaz, G. J., Ferrari, L., Nelson, S. A., Carrasco-Núnez, G., Lopez-Martinez, M., \& UrrutiaFucugauchi, J. (1998). El cinturón volcánico mexicano: un nuevo proyecto multidisciplinario.

Alva-Valdivia, L. M., Goguitchaichvili, A., Ferrari, L., Rosas-Elguera, J., Urrutia-Fucugauchi, J., \& Zamorano-Orozco, J. J. (2000). Paleomagnetic data from the Trans-Mexican Volcanic Belt. Earth, Planets and Space, 52(7), 467-478.

Alva-Valdivia, L. M. (2005). Comprehensive paleomagnetic study of a succession of Holocene olivine-basalt flow: Xitle Volcano (Mexico) revisited. Earth, planets and space, 57(9), 839-853.

Alva-Valdivia, L. M., Agarwal, A., Caballero-Miranda, C., García-Amador, B. I., Morales-Barrera, W., Rodríguez-Elizarraráz, S., \& Rodríguez-Trejo, A. (2017). Paleomagnetic and AMS studies of the El Castillo ignimbrite, central-east Mexico: Source and rock magnetic nature. Journal of Volcanology and Geothermal Research, 336, 140-154.

Alva-Valdivia, L. M., Agarwal, A., García-Amador, B., Morales-Barrera, W., Agarwal, K. K., Rodríguez, S., \& Gonzalez-Rangel, J. A. (2019). Paleomagnetism and tectonics from the late Pliocene to late Pleistocene in the Xalapa monogenetic volcanic field, Veracruz, Mexico. Geological Society of America Bulletin.

Arce, J. L., Layer, P. W., Lassiter, J. C., Benowitz, J. A., Macías, J. L., \& Ramírez-Espinosa, J. (2013). $40 \mathrm{Ar} / 39 \mathrm{Ar}$ dating, geochemistry, and isotopic analyses of the quaternary Sierra de Chichinautzin volcanic field, south of Mexico City: implications for timing, eruption rate, and distribution of volcanism. Bulletin of Volcanology, 75(12), 774.

Arce, J. L., Muñoz-Salinas, E., Castillo, M., \& Salinas, I. (2015). The 2000 yr BP Jumento volcano, one of the youngest edifices of the Sierra de Chichinautzin Volcanic Field, Central Mexico. Journal of Volcanology and Geothermal Research, 308, 30-38.

Bloomfield, K. (1975). A late-Quaternary monogenetic volcano field in central Mexico. Geologische Rundschau, 64(1), 476-497.

Bloomfield, K. (1974). The age and significance of the Tenango Basalt, central Mexico. Bulletin Volcanologique, 37(4), 586-595.

Böhnel, H., Morales, J., Caballero, C., Alva, L., McIntosh, G., Gonzalez, S., \& Sherwood, G. (1997). Variation of rock magnetic parameters and paleointensities over a single Holocene lava flow. Journal of geomagnetism and geoelectricity, 49(4), 523-542.

Böhnel, H., \& Molina-Garza, R. (2002). Secular variation in Mexico during the last 40,000 years. Physics of the Earth and Planetary Interiors, 133(1-4), 99-109.

Böhnel, H., Biggin, A. J., Walton, D., Shaw, J., \& Share, J. A. (2003). Microwave palaeointensities from a recent Mexican lava flow, baked sediments and reheated pottery. Earth and Planetary Science Letters, 214(1), 221-236.

Brown, M.C., F. Donadini, M. Korte, A. Nilsson, K. Korhonen, A. Lodge, S.N. Lengyel and C.G. Constable, GEOMAGIA50.v3: 1. General structure and modifications to the archeological and volcanic database, Earth Planets Space 67:83, doi:10.1186/s40623-015-0232-0.

Constable, C., Korte, M., \& Panovska, S. (2016). Persistent high paleosecular variation activity in southern hemisphere for at least 10000 years. Earth and Planetary Science Letters, 453, 78-86.

Cox, A. (1969). Confidence limits for the precision parameter $\kappa$. Geophysical Journal International, 17(5), 545-549.

Cromwell, G., Johnson, C. L., Tauxe, L., Constable, C. G., \& Jarboe, N. A. (2018). PSV10: A global data set for $0-10 \mathrm{Ma}$ time-averaged field and paleosecular variation studies. Geochemistry, Geophysics, Geosystems, 19(5), 1533-1558. 
Day, R., Fuller, M., \& Schmidt, V. A. (1977). Hysteresis properties of titanomagnetites: grain-size and compositional dependence. Physics of the Earth and planetary interiors, 13(4), 260-267.

Del Pozzo, A. M. (1982). Monogenetic vulcanism in sierra Chichinautzin, Mexico. Bulletin Volcanologique, 45(1), 9.

Demant, A. (1978). Características del Eje Neovolcánico Transmexicano y sus problemas de interpretación. Revista mexicana de ciencias geológicas, 2(2), 172-187.

Doubrovine, P. V., Veikkolainen, T., Pesonen, L. J., Piispa, E., Ots, S., Smirnov, A. V., ... \& Biggin, A. J. (2019). Latitude dependence of geomagnetic paleosecular variation and its relation to the frequency of magnetic reversals: Observations from the Cretaceous and Jurassic. Geochemistry, Geophysics, Geosystems.

Dunlop, D. J. (2002). Theory and application of the Day plot (Mrs/Ms versus Hcr/Hc) 2. Application to data for rocks, sediments, and soils. Journal of Geophysical Research: Solid Earth, 107(B3).

Ferrari, L., Garduño, V. H., Pasquare, G., \& Tibaldi, A. (1994). Volcanic and tectonic evolution of central Mexico: Oligocene to present. Geofísica Internacional, 33(1), 91-105.

Ferrari, L., López-Martínez, M., Aguirre-Díaz, G., \& Carrasco-Núñez, G. (1999). Space-time patterns of Cenozoic arc volcanism in central Mexico: From the Sierra Madre Occidental to the Mexican Volcanic Belt. Geology, 27(4), 303-306.

Ferrari, L., Conticelli, S., Vaggelli, G., Petrone, C. M., \& Manetti, P. (2000). Late Miocene volcanism and intra-arc tectonics during the early development of the Trans-Mexican Volcanic Belt. Tectonophysics, 318(1-4), 161-185.

Fisher, R. A. (1953). Dispersion on a sphere. Proc. R. Soc. Lond. A, 217(1130), 295-305.

Gómez-Tuena, A., Orozco-Esquivel, M. T., \& Ferrari, L. (2007). Igneous petrogenesis of the TransMexican volcanic belt. Geological Society of America Special Papers, 422, 129-181.

Gonzalez, S., Sherwood, G., Böhnel, H., \& Schnepp, E. (1997). Palaeosecular variation in Central Mexico over the last 30000 years: the record from lavas. Geophysical Journal International, 130(1), 201-219.

Guilbaud, M. N., Arana-Salinas, L., Siebe, C., Barba-Pingarrón, L. A., \& Ortiz, A. (2015). Volcanic stratigraphy of a high-altitude mammuthus columbi (Tlacotenco, sierra Chichinautzin), central México. Bulletin of Volcanology, 77(3), 17.

Guilbaud, M. N., Siebe, C., \& Agustín-Flores, J. (2009). Eruptive style of the young high-Mg basalticandesite Pelagatos scoria cone, southeast of México City. Bulletin of volcanology, 71(8), 859.

Herrero-Bervera, E., \& Pal, S. (1977). Paleomagnetic study of Sierra de Chichinautzin, Mexico. Geofísica Internacional, 17(2).

Jaimes-Viera, M. C., Martin Del Pozzo, A.L., Layer, P. W., Benowitz, J. A., \& Nieto-Torres, A. (2018). Timing the evolution of a monogenetic volcanic field: Sierra Chichinautzin, Central Mexico. Journal of Volcanology and Geothermal Research, 356, 225-242.

Johnson, C. L., Constable, C. G., Tauxe, L., Barendregt, R., Brown, L. L., Coe, R. S., ... \& Staudigel, H. (2008). Recent investigations of the $0-5$ Ma geomagnetic field recorded by lava flows. Geochemistry, Geophysics, Geosystems, 9(4).

Kirianov, V. Y., Koloskov, A. B., De la Cruz, S., \& Martin, A. L. (1990). The major stages of manifestation of recent volcanism in the Chichinautzin zone. USSR Academy of Sciences, Geological series, 311, 432-434.

Kirschvink, J. L. (1980). The least-squares line and plane and the analysis of palaeomagnetic data. Geophysical Journal of the Royal Astronomical Society, 62(3), 699-718. 
Lanos, P., \& Philippe, A., 2017. Hierarchical Bayesian modelling for combining dates in archaeological context. J. Soc. Fr. Stat., 158(2), 72-88.

Lorenzo-Merino, A., (2016). M.s. Thesis. Historia eruptiva del volcán Pelado (Sierra de Chichinautzin, México). Posgrado en Ciencias de la Tierra. Universidad Nacional Autónoma de México, México D.F. México (89 pp.).

Mahgoub, A. N., Böhnel, H., Siebe, C., \& Chevrel, M. O. (2017). Paleomagnetic study of El Metate shield volcano (Michoacán, Mexico) confirms its monogenetic nature and young age $(\sim 1250$ CE). Journal of Volcanology and Geothermal Research, 336, 209-218.

Mahgoub, A. N., Juárez-Arriaga, E., Böhnel, H., Siebe, C., \& Pavón-Carrasco, F. J. (2019). LateQuaternary secular variation data from Mexican volcanoes. Earth and Planetary Science Letters, 519, 28-39.

McFadden, P. L., \& McElhinny, M. W. (1990). Classification of the reversal test in palaeomagnetism. Geophysical Journal International, 103(3), 725-729.

McFadden, P. L., Merrill, R. T., McElhinny, M. W., \& Lee, S. (1991). Reversals of the Earth's magnetic field and temporal variations of the dynamo families. Journal of Geophysical Research: Solid Earth, 96(B3), 3923-3933.

Mejia, V., Böhnel, H., Opdyke, N. D., Ortega-Rivera, M. A., Lee, J. K. W., \& Aranda-Gomez, J. J. (2005). Paleosecular variation and time-averaged field recorded in late Pliocene-Holocene lava flows from Mexico. Geochemistry, Geophysics, Geosystems, 6(7).

Michalk, D. M., Böhnel, H. N., Nowaczyk, N. R., Aguírre-Diaz, G. J., López-Martínez, M., Ownby, S., \& Negendank, J. F. (2013). Evidence for geomagnetic excursions recorded in Brunhes and Matuyama Chron lavas from the trans-Mexican volcanic belt. Journal of Geophysical Research: Solid Earth, 118(6), 2648-2669.

Mooser, F., Nairn, A. E., \& Negendank, J. F. (1974). Palaeomagnetic investigations of the tertiary and quaternary igneous rocks: VIII a palaeomagnetic and petrologic study of volcanics of the valley of Mexico. Geologische Rundschau, 63(2), 451-483.

Mora Álvarez, G., Caballero Miranda, C., Urrutia Fucugauchi, J., \& Uchiumi, S. (1991). Southward migration of volcanic activity in the Sierra de Las Cruces, basin of Mexico-a preliminary K-Ar dating and palaeomagnetic study. Geofísica Internacional, 30(2).

Morales, J., Goguitchaichvili, A., \& Urrutia-Fucugauchi, J. (2001). A rock-magnetic and paleointensity study of some Mexican volcanic lava flows during the Latest Pleistocene to the Holocene. Earth, planets and space, 53(9), 893-902.

Opdyke, N. D., Kent, D. V., Foster, D. A., \& Huang, K. (2015). Paleomagnetism of Miocene volcanics on Sao Tome: Paleosecular variation at the Equator and a comparison to its latitudinal dependence over the last 5 Myr. Geochemistry, Geophysics, Geosystems, 16(11), 3870-3882.

Ortega-Gutiérrez, F., Mitre-Salazar, L. M., \& Roldan-Quintana, J. (1992). Carta geológica de la República Mexicana. Consejo de Recursos Minerales y en el Instituto de Geología de la UNAM.

Panovska, S., Constable, C. G., \& Brown, M. C. (2018). Global and regional assessments of paleosecular variation activity over the past $100 \mathrm{ka}$. Geochemistry, Geophysics, Geosystems.

Pavón-Carrasco, F. J., Osete, M. L., Torta, J. M., \& De Santis, A. (2014). A geomagnetic field model for the Holocene based on archaeomagnetic and lava flow data. Earth and Planetary Science Letters, 388, 98-109.

Reimer, P. J , Bard, E., Bayliss, A., Beck, J. W., Blackwell, P. G., Bronk Ramsey, C., Buck, C.E., Cheng, H., Edwards, R. L., Friedrich, M., Grootes, P. M., Guilderson, T.P., Haflidason, H., Hajdas, I., Hatté, C., Heaton, T. J., Hoffmann, D. L., Hogg, A. G., Hughen, K.A., Kaiser, K. 
F., Kromer, B., Manning, S. W., Niu, M., Reimer, R. W., Richards, D.A., Scott, E. M., Southon, J. R., Staff, R. A., Turneyand, C. S. M., \& van der Plicht, J., 2013. IntCal13 and Marine13 Radiocarbon Age Calibration Curves 0-50,000 Years cal BP. Radiocarbon, 55(4), 1869-1887.

Ruiz-Martınez, V. C., Osete, M. L., Vegas, R., Nunez-Aguilar, J. I., Urrutia-Fucugauchi, J., \& Tarling, D. H. (2000). Palaeomagnetism of Late Miocene to Quaternary volcanics from the eastern segment of the Trans-Mexican Volcanic Belt. Tectonophysics, 318(1-4), 217-233.

Siebe, C. (2000). Age and archaeological implications of Xitle volcano, southwestern Basin of Mexico-City. Journal of Volcanology and Geothermal Research, 104(1-4), 45-64.

Siebe, C., Rodríguez-Lara, V., Schaaf, P., \& Abrams, M. (2004a). Radiocarbon ages of Holocene Pelado, Guespalapa, and Chichinautzin scoria cones, south of Mexico City: implications for archaeology and future hazards. Bulletin of Volcanology, 66(3), 203-225.

Siebe, C., Rodrí, V., Schaaf, P., \& Abrams, M. (2004b). Geochemistry, Sr-Nd isotope composition, and tectonic setting of Holocene Pelado, Guespalapa and Chichinautzin scoria cones, south of Mexico City. Journal of Volcanology and Geothermal Research, 130(3), 197-226.

Siebe, C., Arana-Salinas, L., \& Abrams, M. (2005). Geology and radiocarbon ages of Tláloc, Tlacotenco, Cuauhtzin, Hijo del Cuauhtzin, Teuhtli, and Ocusacayo monogenetic volcanoes in the central part of the Sierra Chichinautzin, México. Journal of volcanology and geothermal research, 141(3-4), 225-243.

Tauxe, L., Constable, C., Johnson, C. L., Koppers, A. A., Miller, W. R., \& Staudigel, H. (2003). Paleomagnetism of the southwestern USA recorded by 0-5 Ma igneous rocks. Geochemistry, Geophysics, Geosystems, 4(4).

Urrutia-Fucugauchi, J. (1996). Palaeomagnetic study of the Xitle-Pedregal de San Angel lava flow, southern Basin of Mexico. Physics of the earth and planetary interiors, 97(1-4), 177-196.

Urrutia-Fucugauchi, J., \& Martin del Pozzo, A. L. (1993). Implicaciones de los datos paleomagneticos sobre la edad de la Sierra de Chichinautzin, cuenca de Mexico. Geofísica Internacional, 32(3).

Vlag, P., Alva-Valdivia, L., De Boer, C. B., Gonzalez, S., \& Urrutia-Fucugauchi, J. (2000). A rockand paleomagnetic study of a Holocene lava flow in Central Mexico. Physics of the Earth and Planetary Interiors, 118(3), 259-272. 